\title{
SEPSIS NEONATORUM DAN PNEUMONIA PADA BAYI ATERM
}

\author{
Praevilia M. Salendu
}

\author{
Bagian Ilmu Kesehatan Anak Fakultas Kedokteran Universitas Sam Ratulangi Manado \\ Email: praeviliamd@yahoo.co.id
}

\begin{abstract}
Sepsis neonatorum is the most frequent cause of admission to a hospital and of death in developing and developed countries. Microorganisms such as Gram positive and negative bacteria, viruses, parasites, and fungi can be the etiological factors. We reported a case of a female neonatus, aterm, and born with caesarean section due to fetal distress. After birth, the neonatus did not spontaneously cry and suffered from asphyxia. The risk factor of this sepsis neonatorum were the early rupture of the amnion membrane associated with an unpleasant odor. Besides that, the mother suffered from a urinary tract infection and fluor albus during pregnancy. Blood examinations showed moderate leucocytosis, slight thrombocytopenia, and a positive C-reactive protein. Chest X-ray showed infiltration in both lungs, indicating pneumonia. The blood culture confirmed Staphylococcus aureus (sensitive to meropenem). Conclusion: Based on all the tests performed, the diagnosis was an aterm neonatus with sepsis neonatorum and pneumonia.
\end{abstract}

Keywords: sepsis, neonatus, pneumonia.

\begin{abstract}
Abstrak: Sepsis neonatorum merupakan penyebab tersering dari perawatan di rumah sakit dan kematian neonatus baik di negara berkembang maupun negara maju. Mikroba seperti bakteri Gram positif dan negatif, virus, parasit, serta jamur dapat menjadi faktor etiologi. Kami melaporkan kasus seorang bayi perempuan, aterm, yang lahir dengan seksio sesaria oleh karena gawat janin. Setelah lahir, bayi tidak langsung menangis, dan memperlihatkan gejala asfiksia. Faktor risiko sepsis neonatorum ialah ketuban pecah dini dan air ketuban berbau. Selain itu, ibu pasien menderita infeksi saluran kemih dan fluor albus pada saat hamil. Pemeriksaan darah menunjukkan leukositosis sedang, trombositopenia ringan, dan C-reaktif protein positif. Foto toraks memperlihatkan adanya infiltrat pada kedua lapangan paru yang mengindikasikan suatu pneumonia. Kultur darah mengonfirmasikan stafilokokus aureus yang sensitif terhadap meropenem. Simpulan: Berdasarkan hasil pemeriksaan ditegakkan diagnosis bayi aterm dengan sepsis neonatorum dan pneumonia.
\end{abstract}

Kata kunci: sepsis, neonatus, pneumonia.

Sepsis neonatorum adalah infeksi sistemik oleh sebab masuknya kuman kedalam tubuh disertai manifestasi klinis yang terjadi pada neonatus. Sepsis neonatorum merupakan salah satu penyebab tersering pada neonatus untuk dirawat di rumah sakit dan kematian neonatus baik di negara berkembang maupun negara maju. ${ }^{1,2}$ Diperkirakan lebih dari 20\% neonatus menderita sepsis yang menyokong 30-50\% dari total kematian di negara berkembang. Angka kematian neonatus di Asia Tenggara dilaporkan 39 per 1000 kelahiran hidup. ${ }^{3}$

Sepsis dapat disebabkan oleh berbagai macam mikroorganisme seperti bakteri Gram positif maupun negatif, virus, parasit dan jamur. Sepsis neonatorum dapat dibedakan atas sepsis neonatorum awitan dini pada neonatus berusia $<72$ jam, dan awitan lambat pada neonatus berusia $>72$ jam. $^{4}$

Pneumonia merupakan salah satu infeksi yang tersering pada neonatus dan salah satu penyebab terpenting kematian perinatal. Diperkirakan 3,9 juta dari 10,8 
juta kematian setiap tahunnya terjadi pada 28 hari pertama kehidupan. ${ }^{5}$ Pneumonia neonatal merupakan infeksi parenkim paru dengan terjadinya serangan dalam beberapa jam sejak kelahiran, yang dapat disamakan dengan kumpulan gejala-gejala sepsis. Infeksi dapat ditularkan melalui plasenta, aspirasi, atau diperoleh setelah kelahiran. ${ }^{6}$

Kami melaporkan kasus seorang bayi perempuan aterm dengan sepsis neonatorum dan pneumonia yang dirujuk dari R.S. Liunkendage Tahuna Sangihe.

\section{LAPORAN KASUS}

Seorang bayi perempuan aterm dengan berat badan $3800 \mathrm{~g}$, panjang badan $53 \mathrm{~cm}$, yang lahir dengan seksio sesaria oleh karena gawat janin. Saat lahir, bayi tidak langsung menangis dan disertai asfiksia. Setelah dirawat beberapa jam bayi terdengar merintih. Bayi telah dirawat di RSU Liukendage Tahuna selama 5 hari tanpa menunjukkan perbaikan, kemudian bayi dirujuk ke RSUP Prof. Dr. R.D. Kandou Manado.

Faktor risiko pada bayi yaitu ketuban pecah dini (12 jam) dengan air ketuban berbau sedangkan faktor ibu ialah infeksi saluran kemih dan keputihan selama kehamilan. Riwayat kehamilan ibu (hamil anak ke-2) secara teratur memeriksakan kehamilannya ke dokter umum.

Pada pemeriksaan fisik didapatkan seorang bayi perempuan berusia 6 hari, status gizi baik, keadaan umum tampak sakit, aktivitas menurun, refleks fisiologik menurun, dan terdapat sesak napas disertai pernapasan cuping hidung. Denyut jantung $136 \mathrm{kali} /$ menit, frekuensi pernafasan 82 kali/menit dengan suhu badan $38,4^{\circ} \mathrm{C}$. Tidak ditemukan anemia, sianosis, maupun ikterus. Pada pemeriksaan toraks terlihat gerakan pernapasan simetris, adanya retraksi subkostal, interkostal, dan sifoid. Pada pemeriksaan jantung terdengar bising sedangkan pada paru-paru terdengar ronki basah kasar pada kedua lapangan paru. Pemeriksaan abdomen tidak menunjukkan kelainan. Ekstremitas teraba hangat dengan waktu pengisian kapiler $<3$ detik. Genitalia dan anus tidak memperlihatkan kelainan

Hasil pemeriksaan laboratorium menunjukkan hemoglobin 15,3 g/dL, hematokrit 43,5\%, hitung leukosit $17.140 / \mathrm{mm}^{3}$, hitung trombosit $25.000 / \mathrm{mm}^{3}$, dan C-reaktif protein (CRP) positif (56 mg/L). Hapusan darah tepi menunjukkan leukositosis sedang dan trombositopenia ringan. Foto toraks memperlihatkan adanya infiltrat di kedua lapangan paru, dengan hasil ekspertisi suatu pneumonia. Hasil kultur darah menunjukkan Stafilokokus aureus dengan kepekaan terhadap meropenem.

Diagnosis yang ditegakkan ialah bayi aterm dengan sepsis neonatorum dan pneumonia.

Terapi yang diberikan yaitu pemasangan CPAP (Fi O2 50 \%, flow 8 Lpm, PEEP 5), cairan partial parenteral feeding, sedangkan pemberian per oral dihentikan untuk sementara. Pemberian antibiotik ialah meropenem 2 x 80 mg secara intravena.

Pada pengamatan lanjut, keadaan pasien menunjukkan perbaikan sehingga diberikan susu 8 x50 cc, yang ditingkatkan secara bertahap. Prognosis pasien baik, dan pasien dipulangkan setelah perawatan hari ke-30.

\section{BAHASAN}

Sepsis neonatorum adalah suatu sindrom klinis bakteriemia yang ditandai oleh adanya gejala dan tanda sistemik pada bulan pertama kehidupan serta hasil kultur darah yang positif. Insidens sepsis neonatorum di negara berkembang masih lebih tinggi dibandingkan dengan negara maju. Di rumah sakit Cipto Mangunkusumo Jakarta dilaporkan insidens sepsis neonatorum masih tinggi, yaitu mencapai $13,7 \%$ dengan angka kematian $14 \%{ }^{7}$

Pada sepsis neonatorum terjadi infeksi secara vertikal dari penyakit ibu atau infeksi yang diderita ibu selama persalinan atau kelahiran. Infeksi pada awal minggu pertama kehidupan berhubungan dengan mikro-organisme yang ditularkan dari ibu kepada janin dan memiliki epidemiologi 
yang berbeda dengan infeksi yang didapat setelah periode neonatal. Kolonisasi awal pada neonatus terjadi setelah ketuban pecah saat proses kelahiran. Pada ketuban pecah dini $>24$ jam, bakteri dari vagina dapat naik ke atas. Pada beberapa kasus dilaporkan terjadinya inflamasi membran janin, tali pusat, dan plasenta. ${ }^{2,8}$

Karakteristik ibu dan janin yang berhubungan dengan sepsis awitan dini telah banyak diteliti. Faktor ibu meliputi demam intrapartum $\left(>37,5^{0} \mathrm{C}\right)$, korioamnionitis, ketu-ban pecah dini $>18$ jam, cairan ketuban berwarna hijau keruh dan berbau, persalinan dan kehamilan kurang bulan, serta kehamilan multipel. Faktor risiko bayi meliputi usia gestasi $<37$ minggu, nilai APGAR rendah, dan bayi dengan berat badan lahir sangat rendah. ${ }^{8}$

Di negara maju, penyebab sepsis neonate-rum ialah kelompok kuman Beta strepto-kokus, E. coli, Hemofilus influenza, dan Listeria monositogenes. Umumnya, di negara berkembang termasuk Indonesia, sepsis neonatorum disebabkan oleh kuman enterik Gram negatif seperti Enterobakter Sp, Klebsiela Sp, dan Coli Sp., ${ }^{2,9}$

Diagnosis sepsis neonatorum ditegakkan berdasarkan adanya faktor risiko sepsis pada ibu maupun bayi. Faktor-faktor risiko sepsis tersebut terdiri dari faktor risiko mayor dan minor. ${ }^{7}$ Yang termasuk faktor risiko mayor yaitu: ketuban pecah dini $>18$ jam, ibu demam saat intraparum (suhu $>38^{\circ} \mathrm{C}$ ), korioamnionitis, air ketuban berbau, dan denyut jantung janin $>160$ $\mathrm{x} / \mathrm{menit}$. Faktor risiko minor meliputi ketuban pecah dini $>12$ jam, ibu demam saat intrapartum (suhu $>37,5^{\circ} \mathrm{C}$ ), nilai APGAR rendah, berat badan lahir sangat rendah $(<1.500 \mathrm{~g})$, usia gestasi $<37$ minggu, keputihan pada ibu yang tidak diobati, serta ibu dengan atau terangka infeksi saluran kemih yang tidak diobati.

Diagnosis sepsis neonatorum ditegakkan bila didapatkan 2 faktor risiko mayor atau 1 faktor risiko mayor ditambah dengan 2 faktor risiko minor. ${ }^{7,10}$ Diagnosis sepsis diperberat oleh adanya gambaran klinis sepsis berupa gangguan respirasi, suhu tidak stabil, gangguan sirkulasi, menurunnya aktivitas, rewel, asupan yang buruk, dan ikterus patologik. ${ }^{8}$

Pemeriksaan penunjang yang perlu dilakukan bila terdapat kecurigaan sepsis ialah septic workup yang terdiri dari kultur darah dan pemeriksaan darah rutin yang meliputi leukopenia atau leukositosis, trombositopenia, laju endap darah meningkat, rasio neutrofil imatur/total >0,2 (20\%), serta CRP yang positif. Sampai saat ini, kultur darah masih merupakan baku emas untuk menegakkan diagnosis sepsis neonatorum, tetapi yang menjadi kendala ialah hasil diperoleh setelah 2-5 hari. ${ }^{2}$

Beberapa peneliti berpendapat bahwa adanya satu tanda klinis yang sesuai dengan infeksi disertai dengan nilai CRP $>10 \mathrm{mg} / \mathrm{L}$ sudah cukup untuk menegakkan diagnosis suatu sepsis neonatorum. Untuk menentukan kriteria standar yang seragam pada sepsis, beberapa peneliti menggabungkan nilai $\mathrm{CRP}>10 \mathrm{mg} / \mathrm{L}$ dan rasio netrofil imatur terhadap netrofil total (IT Ratio) $\geq 0,25$ sebagai kriteria untuk pemberian antibiotika meskipun belum ditemukan gejala sepsis. Philip dan Mills merekomendasikan bahwa semua bayi dengan nilai CRP $>10 \mathrm{mg} / \mathrm{L}$ yang disertai $\geq 1$ gejala klinis atau $\geq 1$ faktor risiko infeksi harus diberlakukan pedoman rawat inap neonatus di NICU dan dimulai terapi antibiotika. Frans et al. juga menggunakan kriteria nilai CRP $>10 \mathrm{mg} / \mathrm{L}$ disertai $\geq 1$ gejala klinis ke arah infeksi untuk mendiagnosis sepsis neonatorum di NICU. ${ }^{11,12}$

Pengobatan umumnya menggunakan antibiotika kombinasi yang bertujuan untuk memperluas cakupan mikroorganisme patogen penyebab. Antibiotika yang dipilih ialah golongan ampisilin, kloksasilin, vankomisin, dan golongan aminoglikosida/ sefalosporin, dengan lama pengobatan yang dianjurkan selama 10-14 hari. ${ }^{13,14}$

Pneumonia merupakan infeksi saluran napas yang serius dan menimbulkan banyak masalah, termasuk sebagai penyebab kematian anak terbesar di negara berkembang. Definisi pneumonia neonatal di Indonesia adalah neonatus dengan gawat napas (sesak, napas cepat, napas berbunyi, frekuensi napas $>60 \mathrm{x} /$ menit, retraksi dada, 
batuk, dan merintih), kultur darah positif atau $\geq 2$ faktor predisposisi (demam intrapartum $>38^{\circ} \mathrm{C}$, ketuban berbau, ketuban pecah dini $>24$ jam), tampilan sepsis (letargi, refleks menurun, hipo/hipertermi, distensi abdomen), X-foto toraks curiga pneumonia (infiltrat kasar/noduler, bercak berkabut, difus granuler, air bronchogram, konsolidasi lobar/segmental) yang tidak membaik dalam 48 jam, laboratorium positif sepsis (IT rasio $>20 \%$, lekositosis/ lekopeni, CRP positif, dan laju endap darah meningkat). ${ }^{15}$ Hanya sekitar $40 \%$ ibu dengan bayi yang menderita pneumonia memiliki faktor risiko seperti demam, ketuban pecah dini $>24$ jam, dan air ketuban berbau, sedangkan $>50 \%$ neonatus yang didiagnosis pneumonia tidak memiliki faktor predisposisi. ${ }^{16}$

Penyebab pneumonia ialah bakteri (Streptokokus grup $\beta$, Stafilokokus aureus, Pseudomonas, E. coli, dan Klebsiella) dan virus. Infeksi paru pada neonatus dapat disebabkan oleh penyebaran infeksi dari vagina atau infeksi nosokomial selama perawatan. Pneumonia dapat disebabkan oleh infeksi bakteri, cairan amnion, atau kolonisasi bakteri di jalan lahir yang berhubungan dengan korioamnionitis dan asfiksia neonate-rum walaupun hubungan asfiksia dan pneumonia yang pasti belum jelas diketahui. $^{17}$

Prognosis pada pasien ini dubia ad bonam oleh karena pasien memperlihatkan respon yang baik terhadap pemberian oksigen dan antibiotika. Pasien dipulangkan dengan keadaan stabil dan sembuh.

\section{SIMPULAN}

Berdasarkan anamnesis, hasil pemeriksaan fisik, pemeriksaan laboratorium darah berupa leukositosis sedang, trombositopenia ringan, dan CRP positif, hasil ekspertisi foto toraks adanya infiltrat pada kedua lapangan paru yang mengindikasikan suatu pneumonia, serta kultur darah yang mengonfirmasikan stafilokokus aureus ditegakkan diagnosis bayi aterm dengan sepsis neonatorum dan pneumonia.

\section{DAFTAR PUSTAKA}

1. Jain NK, Jain VM, Maheshwari S. Clinical profile of neonatal sepsis. Kathmandu Univ Med J. 2003;1:117-20.

2. Escobar GJ, Li D, Amstrong MA, Gardner MN, Folck BF, Verdi JE, et al. Neonatal sepsis workups in infants $>2000$ grams at birth: a populationbased study. Pediatrics. 2000;106:25663.

3. Bradley JS. Management of community acquired pediatrics pneumonia in an era of increasing antibiotic resistance and conjugate vaccines. Pediatric Infect Dis J. 2002;21:592-8.

4. Polin RA. Management of neonatus with suspected or proven early-onset bacterial. Pediatrics. 2012;129(5):100615.

5. Duke T. Neonatal pneumonia in developing countries. Arch Dis Child Fetal Neonatal. 2005;90;211-9.

6. Mc Intosh K. Community acquired pneumonia in children. N England $\mathrm{J}$ Med. 2002;346:429-37.

7. Aminullah A. Sepsis pada bayi baru lahir. In: Kosim MS, Yunanto A, Dewi R, Sarosa GI, Usman A, editors. Buku Ajar Neonatologi (Edisi 1). Jakarta: Badan Penerbit IDAI, 2008; p. 170-85.

8. Chiesa C, Panero A, Osborn JF, Simonetti AF, Pacifico L. Diagnosis of neonatal sepsis: a clinical and laboratory challenge. Clin Chem. 2004;50:279-87.

9. Mosayebi Z, Mouahedian AH, Moniri R. Profile of bacterial sepsis in neonates from Kashan in Iran. J Infect Dis Antimicrob Agents. 2003;20:97-102.

10. Darmawan I. Sepsis neonatorum. In: Darmawan I, editor. Update on sepsis: Paradigma Baru. Jakarta: Farmedia, 2008; p. 25-43.

11. Bender L. Thaarup J, Varming K, Krarup H, Eriksen SE, Ebbesen F. Early and late markers for the detection of early onset neonatal sepsis. Dan Med Bull. 2008;55(4): 219-23.

12. Thermiany AS, Retayasa W, Kardana M, Lila IN. Diagnostic accuracy of septic markers for neonatal sepsis. Paediatr Indones. 2008;48(5): 299-305.

13. Rahman S, Hameed A, Roghani MT, Ullah Z. Multidrugs resistant neonatal sepsis in Peshansar, Pakistan. Arch Dis 
Child Fetal Neonatal. 2002; 87:52-4.

14. Hotchkiss RS, Karl IE. The pathophysiology and treatment of sepsis. N Engl J Med. 2003;348:13850.

15. Duke T. Neonatal pneumonia in developing countries. Arch Dis Child
Fetal Neonatal. 2005;90;211-9.

16. Gaston B. Pneumonia. Pediatr Rev. 2002;23:132-40.

17. Caserta MT. Neonatal pneumonia [online]. 2009 [2012 Sept 6]. Available from: http://www.merck.com/mmpe/see19/ch 279/ch2791.html 